\title{
KEADILAN BAGI ISTRI AKIBAT PUTUSAN BATAL DEMI HUKUM
}

\author{
Umi Supraptiningsih \& Nurul Anisah* \\ Institut Agam Islam Negeri (IAIN) Madura
}

Email: umistainpamekasan@gmail.com

\begin{abstract}
Marriage is carried out in order to create a happy and eternal family according to based on the hand of God. However, sometimes divorce must be exist as it was desired by the husband. Accordingly, he submitted a plea of divorce to the Religious Court to obtain an aproval. As he obtained the aproval from Religious court to divorce his wife, the husband disobeyed the court orders until the time limit was expired. Of course, it lead to the injustice gained by the wife. Accordingly, the current research focused on three aspects, namely (1) the legal consequences of verdict with no pronouncing of a divorce pledge. (2) The marital status of both the husband and the wife as the jurisprudence has been void and (3) The justice for the wife because the verdict has been expired due to disobedience carried out by the husband. Normative research with case study design was accomplished in this study. The finding revealed that the verdict with no statement of divorce pledge carried out by the husband before the deadline will not bring about effects for both the claiment (husband) or the defendant (wife). In other word, the marital status did not change as they were still legally married. In line with justice, the wife was aggrieved by the husband, and she did not gain justice either on her marital status, rights and legal certainty.
\end{abstract}

Keywords: Justice, Verdict of Divorce, Expired

\begin{abstract}
Abstrak
Perkawinan dilaksanakan dalam rangka untuk membentuk kehidupan keluarga yang bahagia dan kekal berdasarkan ketuhanan yang Maha Esa. Namun terkadang ditengah jalan harus terjadi perceraian yang diingikan oleh salah satu pihak, katakan saja suami. Suami mengajukan permohonan cerai talak kepada Pengadilan Agama untuk mendapatkan izin mentalak istrinya, akan tetapi setelah Pengadilan Agama memutuskan terjadinya perceraian, suami justru tidak melaksanakan isi putusan tersebut sampai batas waktu habis (daluwarsa). Kondisi yang demikian sangat merugikan istri. Berdasarkan hal diatas, terdapat tiga permasalahan yang menjadi kajian pokok dalam penelitian ini, yaitu: (1) Akibat hukum suatu putusan yang tidak disertai dengan pengucapan ikrar talak. (2) Status perkawinan dari pihak pemohon dan termohon pasca gugurnya kekuatan hukum putusan Pengadilan Agama. (3) Keadilan bagi istri akibat daluwarsanya putusan yang tidak dilaksankan oleh suami. Jenis penelitian yang dipergunakan dalam penelitian ini adalah penelitian Normatif dengan menggunakan pendekatan kasus (case study). Dari hasil penelitian ini dapat diketahui bahwa suatu putusan yang tidak disertai dengan pengucapan ikrar talak akibat ketidakhadiran pemohon (suami) pada sidang ikrar talak sampai batas waktu pelaksanan putusan yang telah ditentukan oleh Pengadilan tidak akan menimbulkan akibat hukum yang dapat mengikat terhadap para pihaknya. Oleh karena itu perkawinan keduanya tidak putus karena perceraian sehingga mereka masih terikat perkawinan yang sah. Terkait nilai keadilan, istri sangat dirugikan atau digantung oleh suami, istri tidak memperoleh keadilan baik atas status hukum, ha-hak dan kepastian hukumnya.
\end{abstract}

Kata Kunci: Keadilan, Putusan Cerai talak, Daluwarsa

* Dosen Fakultas Syariah Institut Agama Islam Negeri (IAIN) Madura 
ADHKI: Journal of Islamic Family Law

\section{Pendahuluan}

Pernikahan adalah jalan yang dipilihkan Allah untuk hamba-hambanya, supaya mereka dapat terhindar dari hal-hal yang dapat merugikan dirinya sendiri. Allah tidak ingin menjadikan manusia seperti makhluk lain, yang hidup bebas hanya mengikuti nalurinya, oleh sebab itu pernikahan dijadikan sebagai jalan keluar yang dapat ditempuh untuk membatasi perilaku seseorang, karena melalui pernikahanlah kebutuhan pokok manusia dapat tersalurkan secara terhormat, sehingga dapat pula menciptakan generasi baru yang akan mewarisi tugas mulia yang diamanatkan Allah sebagai khalifah di muka bumi ini.

Rasulullah telah menganjurkan kepada setiap ummatnya untuk melaksanakan ibadah suci pernikahan, hal ini diperuntukkan bagi mereka yang mampu untuk melaksanakannya. Mampu dalam arti siap lahir batin serta memiliki rasa tanggung jawab untuk membangun rumah tangga yang sakinah mawaddah dan rahmah. Beliau juga menegaskan dalam sebuah sabdanya yaitu:

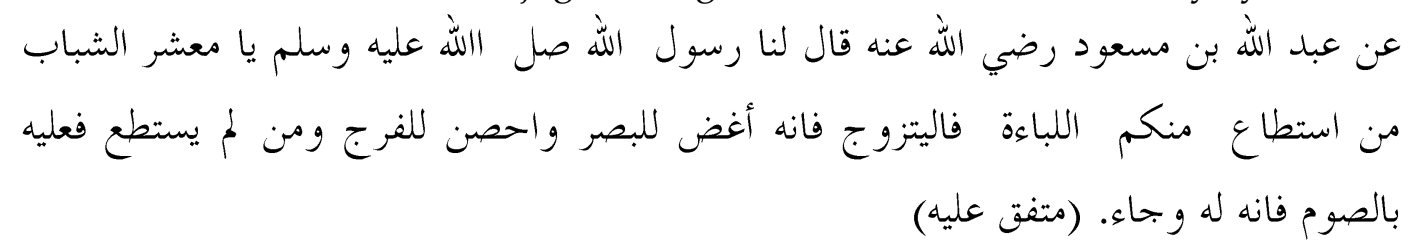

"Abdullah bin Mas'ud radhiyallahu 'anhu berkata, "Rasulullah SAW. bersabda kepada kami, 'Wahai generasi muda, barang siapa di antara kamu telah mampu berkeluarga, hendaknya ia kawin, karena hal itu dapat menundukkan pandangan dan memelihara kemaluan. Barangsiapa belum mampu, hendaknya berpuasa, karena hal itu dapat mengendalikanmu". ${ }^{1}$

Pernikahan dalam bahasa arab disebut dengan al-nikah yang bermakna alwathi' dan al-dammu wa al-tadakhul. Terkadang juga disebut dengan al-dammu wa al-jam'u, atau 'ibarat 'an al-wath' wa al-'aqd yang bermakna bersetubuh, berkumpul dan aqad. beranjak dari makna etimologis inilah para ulama fiqih mendefinisikan perkawinan dalam konteks hubungan biologis. Hal ini sejalan dengan pendapat Hazairin dalam bukunya Amiur Nuruddin dan Azhari Akmal Tarigan, Hukum Perdata Islam di Indonesia yang menyatakan bahwa "inti dari sebuah perkawinan adalah hubungan seksual". Menurutnya tidak ada nikah (perkawinan) bila tidak ada hubungan seksual. ${ }^{2}$

Definisi di atas belum sepenuhnya mampu menggambarkan makna yang sesungguhnya dari sebuah pernikahan. Pernikahan yang dianjurkan dalam Islam bukan hanya untuk menghalalkan hubungan antara seorang laki-laki dan perempuan. Pada dasarnya pernikahan memiliki tujuan yang sangat mulia, yakni untuk mewujudkan keluarga yang bahagia, kekal berdasarkan Ketuhanan Yang Maha Esa, sebagaimana terkandung dalam rumusan Pasal 1 ayat (2)

\footnotetext{
2013), hlm. 423

${ }^{2}$ Amiur Nuruddin, Azhari Akmal Tarigan, Hukum Perdata Islam di Indonesia (Jakarta: Kencana, 2014), hlm. 38.
}

${ }^{1}$ Ibnu Hajar al-Asqalani, Bulughul Maram dan Dalil-Dalil Hukum (Jakarta: Gema Insani, 
Undang-Undang No. 1 Tahun 1974 tentang perkawinan yaitu perkawinan adalah ikatan lahir batin antara seorang pria dan wanita sebagai suami istri dengan tujuan membentuk keluarga (rumah tangga) yang bahagia dan kekal berdasarkan Ketuhanan Yang Maha Esa. Selain itu Kompilasi Hukum Islam juga menyebutkan bahwa "Pernikahan adalah akad yang sangat kuat atau miitsaqan ghalidhan untuk mentaati perintah Allah dan melaksanakannya merupakan ibadah". ${ }^{3}$

Kata miitsaqan ghalidhan ini ditarik dari firman Allah SWT. Yang tercantum dalam surah an-Nisa' ayat 21:

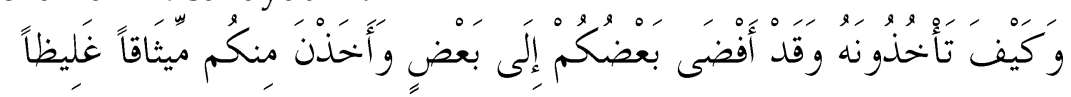

"Bagaimana kamu akan mengambilnya kembali, padahal sebagian kamu telah bergaul (bercampur) dengan yang lain sebagai suami-isteri. Dan mereka (isteri-isterimu) telah mengambil dari kamu perjanjian yang kuat". ${ }^{4}$

Dari rumusan di atas, jelas bahwa perkawinan mengandung arti "ikatan lahir batin antara seorang laki-laki dan perempuan sebagai suami istri", dimana ikatan lahir batin tersebut dimaksudkan agar hubungan suami istri tidak sematamata hanya berupa ikatan lahiriah saja, tetapi kedua-duanya juga harus membina ikatan batin. Jalinan ikatan lahir batin itulah yang akan menjadi fondasi kokoh dalam membangun dan membina keluarga yang bahagia dan kekal.

Tujuan dari perkawinan adalah "membentuk keluarga yang bahagia dan kekal berdasarkan Ketuhanan Yang Maha Esa". Hal ini berarti bahwa dalam kehidupan berumah tangga norma-norma agama harus menjiwai perkawinan dan pembentukan keluarga yang bersangkutan. Sehingga tercapailah tujuan perkawinan yang dicita-citakan oleh Undang-Undang.

Berkenaan dengan tujuan perkawinan tersebut, dimuat dalam KHI Pasal 3 yang berbunyi: "Perkawinan bertujuan untuk mewujudkan kehidupan rumah tangga yang sakinah, mawaddah dan rahmah (tenteram, penuh cinta dan kasih sayang). Tujuan ini juga dirumuskan dalam firman Allah surah ar-Rum ayat 21:

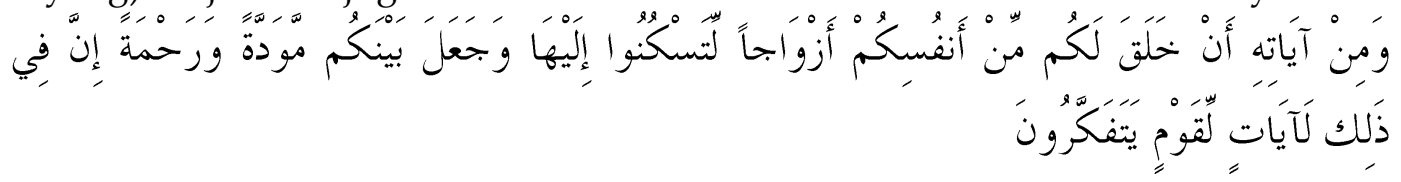

"Dan di antara tanda-tanda kekuasaan-Nya ialah Dia menciptakan untukmu isteri-isteri dari jenismu sendiri, supaya kamu cenderung dan merasa tenteram kepadanya, dan dijadikan-Nya diantaramu rasa kasih dan sayang. Sesungguhnya pada yang demikian itu benar-benar terdapat tanda-tanda bagi kaum yang berfikir".

Tujuan perkawinan adalah membentuk keluarga bahagia yang kekal, tujuan perkawinan ini dapat dielaborasi menjadi tiga hal, pertama, suami istri

${ }^{3}$ Kompilasi Hukum Islam (Jakarta: Permata Press, 2003), hlm. 2.

${ }^{4}$ Amiur Nuruddin, Azhari Akmal Tarigan, Hukum Perdata Islam di Indonesia, hlm. 43. 
saling bantu-membantu serta saling lengkap-melengkapi. Kedua, masing-masing dapat mengembangkan kepribadiannya, dan untuk pengembangan kepribadian itu suami istri harus saling membantu. Ketiga, tujuan terakhir yang ingin dicapai oleh keluarga Indonesia adalah keluarga bahagia yang sejahtera spiritual dan material..$^{5}$

Namun demikian, tidak semua orang dapat membentuk keluarga yang bahagia, kekal, dan sejahtera sesuai dengan tujuan perkawinan yang dicitacitakan oleh Undang-Undang No. 1 Tahun 1974. Hal ini dikarenakan hidup bersama dalam satu atap tidak selamanya akan menciptakan keharmonisan. Seringkali kita temui dalam sebuah rumah tangga terjadi kesalah fahaman atau perbedaan pendapat antara suami istri yang terkadang menimbulkan pertengkaran.

Tidak heran apabila perbedaan cara pandang mewarnai kehidupan rumah tangga seseorang, karena pada dasarnya sepasang suami istri adalah perpaduan dua insan yang berbeda latar belakang keluarga, berbeda latar belakang pendidikan, dan berbeda latar belakang emosional. Hanya saja perbedaan tersebut sering menimbulkan pertengkaran dan perselisihan antara keduanya, yang tidak jarang pertengkaran tersebut berujung pada perceraian.

Setiap orang pasti menginginkan kehidupan rumah tangga yang rukun, damai dan tentram, tetapi semua itu tidaklah mudah. Terkadang seseorang sampai pada titik dimana dia merasa tidak sanggup lagi untuk mempertahankan semuanya, meskipun segala macam cara telah dilakukan untuk mengembalikan keutuhan rumah tangganya. Namun demikian, upaya tersebut sulit untuk membuahkan hasil, yang terjadi malah sebaliknya, apabila tetap dipertahankan akan mendatangkan mudharat yang lebih besar, maka dari itu Islam memberikan jalan keluar kepada mereka yang sudah tidak sanggup lagi untuk hidup bersama dengan jalan perceraian. Perceraian memang tidak dilarang, tetapi ia merupakan perbuatan yang sangat dibenci oleh Allah SWT.

Undang-Undang telah menjelaskan mengenai tata cara yang dapat ditempuh oleh suami istri yang ingin mengakhiri perkawinannya, yaitu melalui gugat cerai atau cerai talak. Gugat cerai adalah perceraian atas keinginan pihak istri, sedang suami tidak menghendakinya. Pengajuan gugatan untuk memutuskan ikatan perkawinan ini dalam hukum Islam dikenal dengan istilah khulu'. ${ }^{6}$ Sedangkan cerai talak diperjelas dalam KHI Pasal 117 yang berbunyi: "Talak adalah ikrar suami di hadapan sidang Pengadilan Agama yang menjadi salah satu sebab putusnya perkawinan, dengan cara sebagaimana dimaksud dalam Pasal 129, 130 dan 131".7

Pasal 115 Kompilasi Hukum Islam menjelaskan bahwa "Perceraian hanya dapat dilakukan di depan sidang Pengadilan Agama setelah Pengadilan Agama

${ }^{5}$ Ibid, hlm. 51.

${ }^{6}$ Amiur Nuruddin, Azhari Akmal Tarigan, Hukum Perdata Islam di Indonesia, hlm. 208.

${ }^{7}$ Kompilasi Hukum Islam, hlm. 36. 
tersebut berusaha dan tidak berhasil mendamaikan kedua belah pihak." Sejalan dengan itu, Undang-Undang No. 1 Tahun 1974 Pasal 39 juga menyebutkan bahwa:

a. Perceraian hanya dapat dilakukan di depan sidang Pengadilan setelah Pengadilan yang bersangkutan berusaha dan tidak berhasil mendamaikan kedua belah pihak.

b. Untuk melakukan percerain harus ada cukup alasan bahwa antara suamiistri itu tidak akan dapat hidup rukun sebagai suami istri.

Ketentuan di atas mengandung tiga aspek hukum yang harus di tempuh untuk proses perceraian, baik itu cerai talak atupun cerai gugat. Yaitu:

a. Setiap perceraian hanya diakui apabila dilakukan di depan sidang Pengadilan.

b. Dalam proses persidangan hakim wajib terlebih dahulu mendamaikan kedua belah pihak.

c. Untuk melakukan perceraian harus cukup alasan, sebagaimana telah diatur oleh peraturan perundang-undangan.

Apabila seorang suami hendak menceraikan istrinya, jalur hukum yang harus ditempuh adalah melalui pengajuan permohonan ikrar talak kepada Pengadilan Agama. Suami diberi hak oleh Undang-Undang untuk menjatuhkan talak terhadap istrinya dengan berpedoman pada ketentuan-ketentuan sebagai berikut:

1. Perceraian harus dilakukan di depan sidang Pengadilan

2. Perceraian harus disertai alasan-alasan sebagaimana telah diatur UndangUndang

3. Mengikuti prosedur sebagaimana diatur dalam Pasal 66 Undang-Undang No. 7 Tahun 1989 Jo. Undang-Undang No. 3 Tahun 2006 Jo. UndangUndang No. 50 Tahun 2009 dan ketentuan perundang-undangan lainnya. ${ }^{8}$

Setiap perceraian harus dilakukan di depan sidang Pengadilan. Mengapa demikian, karena dalam Penjelasan Umum Undang-Undang No. 7 Tahun 1989 tentang Peradilan Agama dijelaskan bahwa Undang-Undang perkawinan bertujuan antara lain untuk melindungi kaum wanita khususnya pihak istri. Di samping itu, secara yuridis Undang-Undang tersebut juga bertujuan untuk mendapatkan kepastian hukum.

Perceraian yang dilakukan di luar Pengadilan, sama halnya dengan suatu perkawinan yang dilakukan tanpa dicatatkan. Ia tidak diakui oleh hukum, dan oleh karenanya tidak dilindungi hukum. Suatu perceraian yang dilakukan di luar Pengadilan akan menimbulkan kesukaran bagi si istri atau bahkan bagi si suami. Hal itu karena hampir dapat dipastikan bahwa dalam setiap talak yang dijatuhkan oleh suami terhadap istrinya tidak pernah memperhitungkan hak-hak

${ }^{8}$ M. Anshary MK, Hukum Perkawinan Di Indonesia (Yogyakarta: Pustaka Pelajar, 2015), hlm. 72 . 
istri sebagai akibat dari perceraian tersebut. Selain itu, tidak pula dapat dipastikan apakah talak yang dijatuhkan oleh suami benar-benar berdasarkan alasan-alasan yang dibenarkan oleh agama atau tidak.

Salah satu prinsip Undang-Undang Perkawinan adalah mempersulit terjadinya perceraian, suami yang diberi hak mutlak untuk mentalak istrinya tidak semena-mena dapat menggunakan haknya. Hak seorang suami untuk mentalak istrinya dapat terjadi bilamana didasarkan pada alasan-alasan perceraian sebagaimana diatur dalam Pasal 19 Peraturan Pemerintah No. 9 Tahun 1975 tentang pelaksanaan Undang-Undang No. 1 Tahun 1974 Jo. Pasal 116 Kompilasi Hukum Islam. ${ }^{9}$

Menurut ketentuan Pasal 66 ayat (1) Undang-Undang No. 7 Tahun 1989 tentang Peradilan Agama menyebutkan bahwa seorang suami yang beragama Islam, yang akan menceraikan istrinya mengajukan permohonan kepada Pengadilan Agama untuk mengadakan sidang ikrar talak. Selanjutnya Pasal 70 ayat (3) Undang-Undang No. 7 Tahun 1989 menyebutkan bahwa terhadap putusan yang telah mempunyai kekuatan hukum tetap, Pengadilan Agama selanjutnya menentukan hari sidang ikrar talak dengan memanggil suami dan istri atau wakilnya untuk menghadiri sidang tersebut.

Sudah barang tentu sangat bijaksana apabila sidang penyaksian ikrar talak segera dilaksanakan beberapa saat setelah putusan memperoleh kekuatan hukum tetap. Tujuannya selain untuk memenuhi tuntutan asas sederhana, cepat dan biaya ringan, sekaligus agar dapat memberi kepastian kepada suami istri untuk menempuh jalan kehidupan baru. Terutama kepada pihak istri sangat penting artinya supaya dia tidak berada dalam "kalmu'allaqah" yakni dalam keadaan terombang-ambing yang berkelamaan. Hal ini sangat tidak dikehendaki oleh ajaran Islam, ${ }^{10}$ sebagaimana diperingatkan dalam surah an-Nisa' ayat 129 , yaitu:

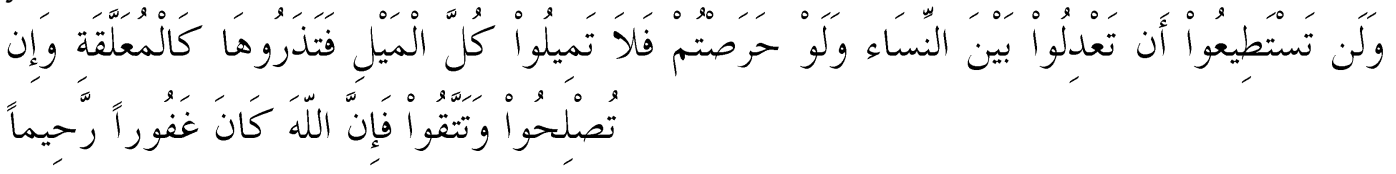

"Dan kamu sekali-kali tidak akan dapat berlaku adil di antara isteri-isteri(mu), walaupun kamu sangat ingin berbuat demikian, karena itu janganlah kamu terlalu cenderung (kepada yang kamu cintai), sehingga kamu biarkan yang lain terkatung-katung. Dan jika kamu mengadakan perbaikan dan memelihara diri (dari kecurangan), maka sesungguhnya Allah Maha Pengampun lagi Maha Penyayang".

Jika pada hari sidang ikrar talak, ternyata suami sebagai pemohon tidak bersedia mengucapkan ikrar talak atau tidak datang menghadap di depan persidangan, maka suami diberi kesempatan oleh Undang-Undang untuk berpikir dalam tenggang waktu maksimal 6 (enam) bulan sejak hari sidang

${ }^{9}$ Ibid, hlm. 80 .

${ }^{10}$ Abdul Mujib AY, Gugurnya Kekuatan Putusan Pengadilan Agama, hlm. 2. 
penyaksian ikrar talak tersebut, sebagaimana ketentuan Pasal 70 ayat (6) Undang-Undang No. 7 Tahun 1989.11

Namun demikian, dalam prakteknya seringkali suami atau wakilnya tidak hadir dalam pelaksanaan sidang ikrar talak, bahkan sampai batas waktu yang telah ditentukan oleh Undang-Undang, seperti kasus yang terjadi di Pengadilan Agama Pamekasan dengan No. perkara: 0092/Pdt.G/2015/PA.Pmk Jo. 0032/Pdt.G/2015/PTA.Sby., dimana suami mengajukan permohonan kepada Pengadilan Agama untuk menceraikan istrinya dengan alasan sudah tidak ada kecocokan dalam membina rumah tangga, suami juga memohon kepada Pengadilan Agama untuk memberikan izin menjatuhkan talak terhadap istrinya. Dengan pertimbangan dan penilaian dari Pengadilan, akhirnya Pengadilan Agama mengabulkan permohonan talak suami tersebut untuk menjatuhkan talak terhadap istrinya di depan persidangan. Akan tetapi dalam sidang penyaksian ikrar talak yang telah ditentukan pihak suami atau wakilnya tidak hadir setelah dipanggil secara sah dan patut oleh Pengadilan Agama Pamekasan.

Hal ini tentu menjadi tanda tanya besar apabila seorang suami yang sudah bersikukuh untuk menceraikan istrinya dari awal sampai pada proses pesidangan berlangsung, ternyata suami tidak menghadiri sidang penyaksian ikrar talak bahkan sampai batas waktu 6 (enam) bulan. Hal ini juga dirasa sangat merugikan bagi pihak termohon (pihak istri), yang telah begitu banyak mengorbankan tenaga dan juga biaya untuk memenuhi tuntutan dari pihak pemohon.

Berdasarkan paparan di atas, maka ada beberapa permasalahan yang perlu dibahas, yaitu pertama : Bagaimana akibat hukum suatu putusan yang tidak disertai dengan pengucapan ikrar talak? dan kedua : Bagaimana keadilan bagi istri akibat putusan batal demi hukum?

\section{Hasil Penelitian dan Pembahasan}

Suami yang ingin menceraikan istrinya harus mengajukan permohonan kepada Pengadilan Agama yang mewilayahi tempat kediaman istri untuk memperoleh izin menjatuhkan talak. Apabila istri bertempat tinggal di luar negeri, maka permohonan tersebut dapat diajukan ke Pengadilan Agama yang mewilayahi tempat kediaman pemohon (suami). Sedangkan apabila keduaduanya tinggal di luar negeri, maka permohonannya dapat diajukan ke Pengadilan Agama yang wilayah hukumnya meliputi tempat perkawinan mereka berlangsung atau kepada Pengadilan Agama Jakarta Pusat, sebagaimana dalam ketentuan Pasal 66 Undang-Undang No. 7 Tahun 1989.

Permohonan yang diajukan oleh suami tidak serta merta dikabulkan oleh Pengadilan Agama, melainkan harus melalui pertimbangan yang matang oleh majelis hakim yang memeriksa dan mengadili perkara tersebut. Apabila permohonan izin ikrar talak telah dikabulkan dan putusan telah memiliki

${ }^{11}$ Ropaun Rambe, Implementasi Hukum Islam (Jakarta: Perca, 2001), hlm. 137. 
kekuatan hukum tetap, maka pemohon berkewajiban untuk melaksanakan sidang ikrar talak. Hal ini ditegaskan dalam Pasal 70 ayat (3) Undang-Undang No. 7 Tahun 1989 tentang Peradilan Agama yang telah diubah dengan UndangUndang No. 3 Tahun 2006 dan Undang-Undang No. 50 Tahun 2009 tentang Peradilan Agama, yang berbunyi:

Setelah penetapan tersebut memperoleh kekuatan hukum tetap, Pengadilan menentukan hari sidang penyaksian ikrar talak, dengan memanggil suami dan istri atau wakilnya untuk menghadiri sidang tersebut."

Namun demikian, setelah Pengadilan menentukan hari sidang ikrar talak (PHS), seringkali suami tidak hadir dalam pelaksanaan sidang tersebut dengan alasan yang beragam, antara lain dimana ketidakhadiran suami disebabkan karena kedua belah pihak telah rukun kembali, atau karena suami menghindari tuntutan dari pihak istri atas nafkah yang menjadi hak-hak mereka.

Ikrar talak dilaksanakana atau tidak memang secara mutlak ada di tangan suami, dimana istri sebagai termohon hanyalah diposisikan sebagai objek, artinya istri tidak mempunyai kuasa untuk memaksa suami harus melakukan ikrar talak. Sebenarnya hal ini kembali kepada iktikat dari pihak pemohon, apabila suami beriktikat baik, apapun konsekuensi yang harus ditanggungnya, ia harus tetap melaksanakan ikrar talak di depan siding Pengadilan, akan tetapi apabila pemohon mempunyai iktikat tidak baik, yang pada akhirnya pemohon tidak hadir dalam pelaksanaan sidang ikrar talak, maka ketidak hadiran tersebut dapat dikatakan sebagai bentuk pengingkaran dan pelecehan terhadap lembaga Peradilan Agama. Namun meskipun demikian, tindakan pemohon yang tidak bersedia melakukan ikrar talak tersebut merupakan hak persoanal, dimana Undang-Undang sendiri tidak mengatur secara tegas mengenai hal itu dan tidak pula menentukan sanksi atas perbuatan yang dilakukan oleh pemohon.

Perihal ketidakhadiran pemohon dalam pelaksanaan sidang ikrar talak ini menjadi perhatian khusus, terlebih jika sampai melampaui batas waktu yang telah ditentukan oleh Pengadilan, yakni sampai tenggang waktu 6 bulan. Apabila suami tidak ikrar sampai tenggang waktu tersebut, terhitung sejak ditetapkannya sidang ikrar talak, maka putusan yang telah memiliki kekuatan hukum tetap dapat dinyatakan batal demi hukum atau gugur kekuatan hukumnya sehingga berakibat fatal terhadap gugatan yang diajukan sebelumnya. Sesuai dengan ketentuan Pasal 70 ayat (6) Undang-Undang No. 7 Tahun 1989 tentang Peradilan Agama yang telah diubah dengan UndangUndang No. 3 Tahun 2006 dan Undang-Undang No. 50 Tahun 2009, menyatakan:

"Jika suami dalam tenggang waktu 6 (enam) bulan tidak datang menghadap sendiri atau tidak mengirim wakilnya meskipun telah mendapat panggilan secara sah dan patut, maka gugurlah kekuatan 
penetapan tersebut dan perceraian tidak dapat diajukan lagi berdasarkan alasan yang sama".

Apabila ketentuan di atas tidak dipenuhi oleh pihak pemohon, maka dengan sendirinya gugurlah kekuatan hukum putusan cerai talak tersebut, dan konsekuensinya perceraian tidak dapat diajukan lagi dengan alasan yang sama, sedangkan mengenai akibat yang ditimbulkan dari gugurnya putusan cerai talak itu adalah percerain keduanya dianggap tidak pernah terjadi, perkawinan mereka dianggap tetap utuh dan sah secara hukum, dimana hal ini menandakan bahwa keduanya berhak atas hak dan kewajiban dari masing-masing pihak sebagai suami istri.

Dengan gugurnya putusan Pengadilan Agama dalam permohonan cerai talak berarti para pihak terbebas dari semua tuntutan pihak lainnya, sebab putusan yang batal demi hukum tidak lagi mengikat terhadap para pihak baik pemohon ataupun termohon, sehingga hal ini tentu akan sangat merugikan pihak istri. Bagaimana tidak, hubungan keduanya sudah tidak lagi harmonis karena sudah sejak lama beriktikat untuk berpisah, tetapi pada waktu sidang ikrar talak yang telah ditentukan oleh Pengadilan Agama suami justru tidak hadir, keadaan semacam ini akan semakin menambah penderitaan istri, yang seharusnya mendapat jaminan hukum dengan memperoleh hak-haknya, namun justru sebaliknya istri digantung tanpa ada kepastian yang jelas, tidak terpenuhi hak-haknya dan tidak pula diceraikan.

Sekalipun hak ikrar ada ditangan suami, bukan berarti hak istri dapat ditelantarkan begitu saja, bukan pula istri harus terkatung-katung menunggu suami yang tidak kunjung memberi kepastian, apalagi istri sudah banyak berkorban baik fisik ataupun materi. Maka dari itu, untuk dapat memperoleh hak-haknya, istri dapat menempuh beberapa cara diantaranya melalui proses pidana dan perdata.

Melalui proses pidana istri dapat melaporkan suami kepada pihak kepolisian atas dugaan penelantaran istri dan anak sebagaimana dengan ketentuan Pasal 49 UU No. 23 Tahun 2004 tentang Penghapusan Kekerasan Dalam Rumah Tangga (UU PKDRT). Tindakan suami yang tidak menafkahi anak dan istri, tergolong dalam tindak pidana yang dimaksud dalam Pasal di atas, sehingga dengan bukti-bukti yang kuat istri dapat melaporkan suami kepada pihak kepolisian.

Yang dimaksud dengan penelantaran dalam lingkup rumah tangga dalam Pasal 9 UU PKDRT adalah "melakukan penelantaran kepada orang yang menurut hukum yang berlaku baginya atau karena perjanjian dia wajib memberikan kehidupan, perawatan atau pemeliharaan kepada orang tersebut." sedangkan Pasal 49 UU PKDRT menjelaskan bahwa "setiap orang yang melakukan penelantaran dalam rumah tangga dipidana dengan pidana penjara paling lama 3 (tiga) Tahun atau denda paling banyak Rp. 15.000.000 (lima belas juta rupiah). Begitu juga dengan ketentuan UU No. 23 Tahun 2002 tentang 
Perlindungan Anak, dapat dijadikan sebagai dasar hukum untuk menjerat suami yang menelantarkan anak dan istrinya.

Ketika istri melaporkan suami atas dugaan tersebut dan laporannya sudah diterima oleh pihak kepolisian, maka keduanya akan dipanggil oleh pihak yang berwajib untuk mediasi, polisi akan menyarankan kedua belah pihak untuk menyelesaikan kasusnya secara kekeluargaan, pada kesempatan ini istri dapat meminta suami untuk membayar semua nafkah yang telah dilalaikannya baik sebelum ataupun sesudah pengajuannya kepada pihak kepolisian, apabila suami tetap tidak mengindahkan syarat dan permintaan yang diajukan oleh pihak istri, maka istri dapat melanjutkan kasus tersebut ke jalur hukum. Pemidanaan ini tidak lain hanya untuk memberikan rasa jera kepada suami agar suami memenuhi kewajibannya kepada istri dan anak.

Hal ini akan sangat efektif membuat suami jera untuk tidak melakukan penelantaran kepada istri dan anak-anaknya, jika suami adalah salah satu Pegawai Negeri Sipil, dimana menurut Undang-Undang No. 5 Tahun 2014 tentang Aparatur Sipil Negara disebutkan dalam Pasal 87 ayat (2) bahwa Pegawai Negeri Sipil dapat diberhentikan secara tidak hormat apabila melakukan tindak pidana, selanjutnya dalam Pasal 87 ayat (4) huruf (d) disebutkan bahwa pegawai negeri sipil akan diberhentikan secara tidak hormat apabila mendapat ancaman hukuman penjara di atas dua tahun, dimana ancaman semacam ini akan memberikan tekanan pada suami, karena ia akan kehilangan jabatannya dan pemasukan yang dimiliki setiap bulannya dengan pemecatan tersebut.

Alternatif kedua yang dapat dilakukan oleh pihak istri apabila ia tidak dinafkahi secara lahir oleh suaminya adalah dengan mengajukan gugatan nafkah kepada Pengadilan, pada rinsipnya adalah kewajiban suami melindungi istri dan memenuhi segala keperluan hidup rumah tangganya termasuk kewajiban suami sebagai kepala keluarga untuk memberikan nafkah kepada istri dan anakanaknya, sehingga apabila suami tidak melaksanakan kewajiban tersebut maka secara hukum istri dapat mengajukan gugatan nafkah ke Pengadilan. Sebagaimana ketentuan Pasal 34 ayat (1) Undang-Undang No. 1 Tahun 1974 tentang perkawinan. Berbeda dengan gugat cerai, gugatan nafkah ini tidak ada hubungannya dengan gugat cerai, dengan kata lain gugatan nafkah bisa diajukan istri terhadap suami tanpa harus bercerai.

Selain itu, solusi lain yang dapat ditempuh oleh pihak istri apabila suami tetap melalaikan hak-haknya ialah melalui proses perdata dengan mengajukan gugat cerai kepada Pengadilan Agama yang daerah hukumnya meliputi tempat kediaman penggugat, kecuali apabila penggugat dengan sengaja meninggalkan tempat kediaman bersama tanpa izin dari tergugat. Gugat cerai yang diajukan oleh pihak istri bukan hanya untuk memperoleh semua hak-haknya, tetapi juga untuk kemaslahatan kedua belah pihak terutama bagi pihak istri, karena dengan mengajukan permohonan cerai kepada Pengadilan Agama berarti suami sudah tidak ingin mempertahankan rumah tangganya, terbukti dalam setiap mediasi 
yang dilakukan pada persidangan tingkat pertama sampai persidangan tinggkat banding, keduanya tidak pernah bisa lagi untuk berdamai. Ketidakhadiran suami pada sidang ikrar talak bukan karena keinginannya untuk rujuk kembali, tetapi karena dia merasa tidak menerima atas gugatan balik (rekonvensi) yang diajukan istri dalam jawabannya, sehingga suami tidak melaksanakan ikrar talak bahkan sampai batas waktu pelaksanaan putusan tersebut telah lewat (daluwarsa).

Meskipun istri telah melewati proses yang panjang dan cukup lama pada persidangan sebelumnya, dalam gugat cerai ia tetap harus mengajukan gugatannya sebagaimana pengajuan gugatan pada umumya. Dalam gugatan tersebut istri dapat mencantumkan kembali gugatan baru dan gugatan rekonpensi yang pernah diajukannya dalam permohonan cerai talak, begitu pula dengan semua bukti yang pernah digunakan sebelumya, seperti salinan putusan, bukti-bukti surat dan termasuk juga bukti-bukti yang sempat ditolak oleh hakim pada tingkat pertama dan banding, karena bukti yang pernah ditolak sebelumnya belum tentu akan ditolak oleh majelis hakim yang menyidangkan perkara itu, demikian juga bukti dan kesaksian yang pernah diterima sebelumnya bisa jadi ditolak dan tidak memiliki nilai pembuktian menurut hakim yang lain. Melihat hakim yang menyidangkan perkara tersebut bebeda, maka akan berbeda pula pemikiran dan sudut pandang mereka.

Langkah kedepannya yang bisa dilakukan oleh pihak istri untuk meminimalisir kemungkinan-kemungkinan suami akan melalaikan putusan Pengadilan Agama atas permohonan ikrar talak yang diajukannya adalah istri perlu menyebutkan dalam gugatan rekonpensinya permintaan agar suami mengganti rugi semua biaya yang dikeluarkan istri mulai dari awal sampai akhir persidangan, sebab hakim tidak akan memutus sesuatu yang tidak disebutkan dalam petitum sesuai dengan ketentuan Pasal 178 ayat (3) HIR/Pasal 189 ayat (3) Rbg yang menyatakan bahwa putusan tidak boleh mengabulkan melebihi tuntutan yang dikemukakan dalam gugatan, larangan ini disebut juga dengan asas ultra petitum partium.

\section{Kesimpulan}

Berdasarkan pembhasan yang telah dipaparkan di atas dapat disimpulkan beberapa hal sebagai berikut:

1. Akibat hukum dari putusan yang tidak disertai dengan pengucapan ikrar talak disebabkan karena ketidakhadiran pemohon dalam pelaksanaan sidang ikrar talak adalah menurut Pasal 70 ayat (6) Undang-Undang No. 7 Tahun 1989 tentang Peradilan Agama, tentang hal yang menggugurkan kekuatan hukum putusan cerai talak. Apabila ketentuan yang tertera dalam Pasal tersebut tidak dipenuhi oleh suami, maka dengan sendirinya menurut hukum gugurlah putusan cerai talak itu. Sehingga putusan tersebut tidak lagi dapat mengikat terhadap para pihaknya. 
ADHKI: Journal of Islamic Family Law

2. Ketidakhadiran suami pada waktu pelaksanaan sidang ikrar talak diantaranya karena suami tidak sanggup untuk memenuhi tuntutan istri atas hak-haknya. Oleh karena itu suami tidak melaksanakan isi putusan dengan tidak menghadiri sidang ikrar talak yang telah ditentukan oleh Pengadilan. sehingga apabila istri ingin memperoleh kembali hak-haknya, istri dapat mengajukan gugat cerai kepada Pengadilan Agama. Agar kepastian hukum dapat tercipta maka perlu adanya aturan hukum yang tegas terhadap pihak pemohon (suami) yang tidak bersedia menghadiri sidang ikrar talak, perlu juga adanya sanksi yang tegas terhadap pemohon yang tidak melaksanakan ikrar talak tersebut, misalnya suami harus mengganti semua biaya yang dikeluarkan istri selama proses persidangan dari awal sampai akhir. Perlu adanya peraturan khusus yang mengatur tentang langkah-langkah yang dapat dilakukan istri pasca gugurnya penetapan Pengadilan Agama, agar istri tidak terkatung-katung hanya menunggu kepastian dari suami. Langkah hukum yang dapat ditempuh oleh istri pasca gugurnya penetapan Pengadilan Agama, dapat mengajukan laporan ke pihak kepolisian dengan laporan penelantaran terhadap anak dan istri yang didasarkan pada UUPKDRT dan UU Perlindungan Anak.

\section{Daftar Pustaka}

Anshary MK. Hukum Perkawinan Di Indonesia, Yogyakarta: Pustaka Pelajar, 2015.

Arto, Mukti. Praktek Perkara Perdata Pada Pengadilan Agama, Yogyakarta: Pustaka Pelajar, 2003.

Azwar, Sarifuddin. Metodologi Penelitian, Yogyakarta: Pustaka Pelajar, 2003.

Daud Ali, Muhammad. Hukum Islam dan Peradilan Agama, Jakarta: PT Raja Grafindo Persada, 1997.

Ghozoli, Abdul Rahman. Fiqih Munakahat, Jakarta: Kencana, 2014.

Kompilasi Hukum Islam, Jakarta: Permata Press, 2003.

Laksmi Anindita, Sri dan Lazuardi Adnan. Putusan Pengadilan Agama Sebagai Dasar Pengajuan Guagatan Perbuatan Melawah Hukum Terkait Pelaksanaan Uang Pengganti, Jurnal Hukum \& Pembangunan, 1 (Maret, 2017).

Lubis, Sulaikin. Hukum Acara Perdata Peradilan Agama Di Indonesia, Jakarta: Kencana, 2008.

Manan, Abdul dan M. Fauzan. Pokok-pokok Hukum Perdata Wewenang Peradilan Agama, Jakarta: PT Raja Grafindo Persada, 2002.

Moh. Kasiram, Metodologi Penelitian Kualitatif-Kuantitatif, Yogyakarta: UIN Maliki Press, 2010.

Mujib, Abdul. Gugurnya Kekuatan Putusan Pengadilan Agama.

Nuruddin, Amiur dan Azhari Akmal Taringan. Hukum Perdata Islam Di Indonesia, Jakarta: Kencana, 2014.

Ropaun, Rambe dan A. Mukri Agafi. Implementasi Hukum Islam, Jakarta: Perca, 2001. 
Sabiq, Sayyid. Fiqhus Sunnah, Jakarta: Pena Pundi Aksara, 2006.

Saebani, Beni Ahmad. Metodologi Penelitian Hukum, Bandung: CV Pustaka Setia, 2008.

Soekanto, SoerjoNo. Pengantar Penelitian Hukum, Jakarta: UI Press, 2008.

Sugeng, Bambang dan Sujayadi. Hukum Acara Perdata Dan Dokumen Litigasi Perkara Perdata, Jakarta: Kencana, 2011.

Sugiono, Metode Penelitian Kuantitatif Kualitatif dan RED, Bandung: CV. Alfabeta, 2014.

Zuhriah, Erfaniah. Peradilan Agama Indonesia, Sejarah Pemikiran dan Realita, Malang: Setara Press, 2014. 